\title{
Gall stones size, number, biochemical analysis and lipidogram- an association with gall bladder cancer: a study of 200 cases
}

\author{
Shveta Narang1, Parul Goyal'2, Manjit Singh Bal ${ }^{3}$, Usha Bandlish' ${ }^{3}$ Sunder Goyal ${ }^{4}$ \\ ${ }^{I}$ Department of Pathology, Kalpana Chawla Govt Medical College, Karnal, Haryana, India. \\ ${ }^{2}$ Department of Biochemistry, Kalpana Chawla Govt Medical College, Karnal, India. \\ ${ }^{3}$ Department of Pathology, Govt, Medical College, Patiala, India. \\ ${ }^{4}$ Department of Surgery, Kalpana Chawla Govt Medical College, Karnal, Haryana, India.
}

Received January 22, 2014; Revised May 18, 2014; Accepted June 11, 2014; Published Online June 26, 2014

\section{Original Article}

\begin{abstract}
Purpose: Objective of the study was to find out if there is any relation of number, size and type of gall stones and patient's lipid profile with the occurrence of gall bladder carcinoma (GBC) as presence of gall stones is considered to be the most important risk factor for gall bladder cancer. Methods: 200 specimens of post-cholecystectomy gallbladder were studied. The number, size and type of stones and lipid profile were compared in all these cases. Gross as well as histopathological examination of gall bladders specimens was done. Results: 185 (92.5\%) gall bladders were associated with gall stones. On histopathological examination, malignancy was found in 6 cases (3\%) only and rest 194 cases (97\%) revealed inflammatory/ non-neoplastic pathology. A statistically significant difference was observed in the number of stones in gall bladders with malignancy than those with benign lesions $(\mathrm{P}<0.001)$. Similarly, a statistically significant difference was seen in terms of stone size between gallbladder cancer $(\mathrm{GBC})$ cases and those with benign pathology $(\mathrm{P}<0.005)$. Benign lesions of gall bladders were mostly associated with mixed type of stones whereas malignant cases were associated with pure cholesterol type of stones. No significant relation was found between the patient's lipid profile and occurrence of gallbladder carcinoma (GBC) ( $p>0.005)$. Conclusion: Thus we concluded that as the number, size and cholesterol gall stone increase the risk of gall bladder cancer also increases without any relation with lipid profile.
\end{abstract}

Keywords: Gall Stones; Cancer; Gall Bladder; Lipid Profile

\section{Introduction}

Gallbladder cancer (GBC) was first described by Maximillian Stoll in 1777 and even after 200 years, it is still considered to be an extremely malignant disease with a poor prognosis. ${ }^{1,2}$ Though this type of cancer is uncommon in US and Europe, it is common in Chile, Peru, Japan and Korea. ${ }^{3}$ Comparison of the data from the various population based cancer registries in India indicates that GBC is common in Northern India.

Gallbladder carcinoma (GBC) has a preponderance for the female sex and has been associated with many risk factors. ${ }^{4}$ Epidemiology studies demonstrate a close association between gallbladder carcinoma (GBC) and gall stones. ${ }^{5-11}$ Alt-

Corresponding author: Shveta Narang; Pathology Department, Kalpana Chawla Govt Medical College, Karnal, Haryana, India.

Cite this article as:

Narang S, Goyal P, Bal MS, Bandlish U, Goyal S. Gall stones size, number, biochemical analysis and lipidogram- an association with gall bladder cancer: a study of 200 cases. Int J Cancer Ther Oncol 2014; 2(3):020310. DOI: 10.14319/ijcto.0203.10 hough different associations have been described, gallstones are found to be associated in $70 \%$ to $90 \%$ of the cases of gallbladder cancer and approximately $0.4 \%$ of all patients affected with gallstone disease eventually develop carcinoma of the gallbladder. ${ }^{12}$ The incidence of gallbladder carcinoma (GBC) parallels the prevalence of gallstone disease; large and longstanding gallstones being associated with a higher risk of gallbladder carcinoma (GBC). ${ }^{13}$ The risk of GBC is about four to seven times in patients with gallstones. ${ }^{14,15}$

Gallstones injure the mucosal columnar epithelium of gallbladder and thus result in various changes like metaplasia, dysplasia and neoplasia in gall bladder epithelium. ${ }^{16}$ Higher number of stones, as well as larger and heavier stones have been associated with an increased risk for cancer causation. Large and heavy gallbladder stones causes mechanical trauma to mucosa and thus has been linked to the causation of dysplasia and progression to carcinoma. 
Cholesterol gall stones and mixed gall stones are commonly associated with GBC and both share a number of risk factors, including obesity, high fat diet and hyperlipidemia. ${ }^{17}{ }^{18}$ It is still controversial whether serum cholesterol should be considered as a risk factor for gall stone diseases. ${ }^{19}$ To clarify this, we examined the effect of serum lipids (total cholesterol, triglycerides) and lipoproteins (HDL, LDL) on the risk of gallbladder carcinoma (GBC).

This study was done to find out whether gall stones pose a risk for gallbladder carcinoma (GBC) and if so, which parameter (number, size or type of stones) affects the most. Lipid profile as a risk factor for gallbladder carcinoma (GBC) was also assessed.

\section{Methods and Materials}

The present study comprised of 200 cholecystectomy specimens received in the Department of Pathology of a govt. medical college. The relevant information was gathered from requisition slip accompanying the specimens. It included complete history with the chief complaints, duration of illness, age, sex, occupation, dietary and bowel habits. The specimens were studied macroscopically for evidence of any gross abnormality. For microscopic examination, biopsy sample were taken from different areas of gall bladder including fundus, lateral walls, neck and from thickened area or visible growth if any. Physical examination and biochemical analysis of stones were done in all cases. Lipid profile was estimated in all enrolled patients.

Physical characteristics of stones: Gall stones were assessed in terms of

1) Number: Single/multiple.

2) Size: Averages of two major diameters were taken with the help of verniercaliper. In the event of multiple gall stones, diameter of the largest stone was recorded.

3) Shape: Multifaceted/round/oval.

4) Color: Grayish white/yellow /brown black.

\section{Biochemical Analysis of gall Stones}

Biochemical analysis of gall stones was performed by the method described by Oser. ${ }^{20}$ The gall stones were powdered into fine particles and were analysed qualitatively. The gall stones were analysed for the presence of cholesterol, bile pigments, bile salts, calcium and phosphorous were categorized as mixed/cholesterol/pigmented/combined.

\section{Lipid Profile}

After having written informed consent from all study subjects, overnight fasting blood samples were collected. Within 3 hours of collection, samples were transported to the biochemistry lab, government medical college where samples were processed for the estimation of serum cholesterol, triglycerides, HDL and LDL using the following assays.

(i) Total cholesterol: was analyzed by in vitro enzymatic colorimetric method described by Allain et al. ${ }^{21}$

(ii) Triglycerides: was analyzed by in vitro enzymatic colorimetric method described by McGowan et al. ${ }^{22}$

(iii) HDL-Cholesterol: was determined by enzymatic method after precipitation of serum by phosphotungstate and magnesium chloride as described by Burstein et al. ${ }^{23}$

(iv) LDL-Cholesterol: was determined by the formula devised by Friedewald et al. ${ }^{24}$

GBC cases and gall bladders with benign pathology were then compared with respect to the size, number and type of stones and lipid profile.

\section{Statistics}

Statistical evaluation was performed with SPSS for Windows ${ }^{\circledR}$ using Student's t test and the Pearson correlation test. $P$ values less than 0.005 were regarded as statistically significant. Results are reported as mean \pm SD.

\section{Results}

This study consisted of 200 patients who underwent cholecystectomy. Predominantly the patients were females (176) accounting for $88 \%$ whereas males were only 24 constituting $12 \%$. Female to male ratio was $7.3: 1$. Majority of patients (58\%) were between 31 to 40 years of age.

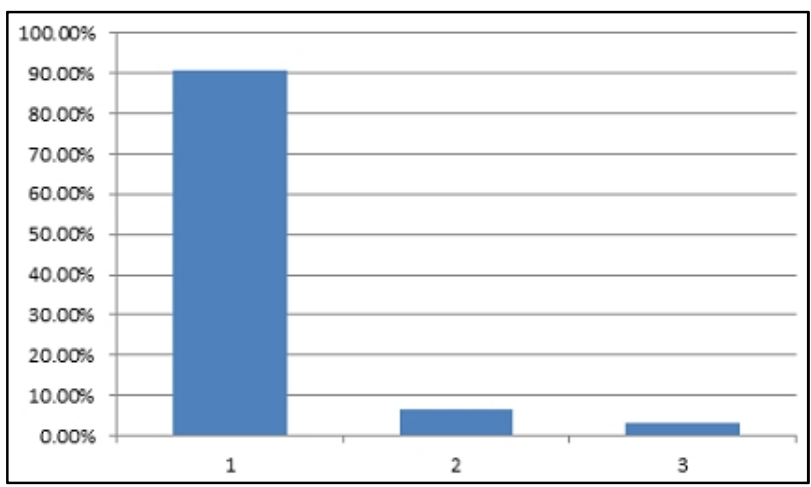

FIG.1: Showing incidence of cholecystitis, cholesterolosis and malignancy of GB.

All specimens were subjected to microscopy and were categorized accordingly. Out of 200 cases, majority of the cases (181) had cholecystitis (90.5\%) and there were 13 cases $(6.5 \%)$ of cholesterolosis and 6 cases of malignancy accounting for $3 \%$ of the total cases (Table 1). All 6 cases (100\%) of GBC were females. Among them, $4(66.67 \%)$ were in $5^{\text {th }}$ and $7^{\text {th }}$ decade. Out of 6 cases of malignancy, 4 (66.67\%) had diffusely growing type (Infiltrating type) of growth and rest 
2 cases (33.33\%) had polypoidal (exophytic) growth protruding within the lumen of the gall bladder. On microscopic examination, all 6 cases were adenocarcinoma.

TABLE 1: Distribution of various lesions of gall bladder $(n=200)$.

\begin{tabular}{|c|c|c|}
\hline Histopathological Diagnosis & $\bar{n}$ & $\%$ age \\
\hline \multicolumn{3}{|l|}{ Cholecystitis } \\
\hline Acute cholecystitis & 07 & 3.5 \\
\hline Chronic cholecystitis & 162 & 81.0 \\
\hline Follicular cholecystitis & 02 & 1.0 \\
\hline Eosinophiliccholecystitis & 03 & 1.5 \\
\hline Xanthogranulomatous & 04 & 2.0 \\
\hline Cholecystitisglandularis & 03 & 1.5 \\
\hline Cholesterolosis & 13 & 6.5 \\
\hline Malignancy & 06 & 3.0 \\
\hline Total & 200 & 100.0 \\
\hline
\end{tabular}

Out of 200 cholecystectomy specimens, 185 gall bladders were associated with gall stones (92.5\%). GBC cases and gall bladders with benign pathology were compared with respect to the size, number and type of stone and serum lipid profile. Following observations were recorded.

\section{Number of stones}

Out of 185 gall bladders with stones, 13 gall bladders (7\%) had single stone and 172 gall bladders (93\%) were having multiple stones.In multiple stones, the number ranged from 2 to 58 . Only 1 case out of 185 cases $(0.54 \%)$ had more than 50 stones.In 5 out of 6 malignant cases there were having $\geq 20$ number of stones while only 20 out of 179 gall bladders with benign pathology, had $\geq 20$ number of stones. Number of stones in patients with GBC was significantly higher than those with benign lesions $(\mathrm{P}<0.001)$ (Table 2). Thus there appears to be a steady increase in the risk of gall bladder cancer with increasing number of stones within the gall bladder.

TABLE 2: Correlation of number, size and type of stones with gall bladder pathology.

\begin{tabular}{|c|c|c|c|}
\hline $\begin{array}{l}\text { Stone } \\
\text { Characteristics }\end{array}$ & $\begin{array}{c}\text { Benign Pathology } \\
(\mathrm{n}=179)\end{array}$ & $\begin{array}{c}\text { Malignancy } \\
(\mathrm{n}=6)\end{array}$ & p-value \\
\hline Number & & & $<0.001$ \\
\hline$<20$ & 159 & 1 & \\
\hline$\geq 20$ & 20 & 5 & \\
\hline Size & & & $<0.005$ \\
\hline$<3 \mathrm{~cm}$ & 172 & 4 & \\
\hline$\geq 3 \mathrm{~cm}$ & 7 & 2 & \\
\hline Type & & & $<0.001$ \\
\hline Mixed & 166 & 2 & \\
\hline Cholesterol & 9 & 4 & \\
\hline Pigmented & 3 & - & \\
\hline Combined & 1 & - & \\
\hline
\end{tabular}

*This group is a subset of those cases which have gall stones $(\mathrm{n}=185)$ size of stones.

\section{Size of stones}

Out of 185 gall bladders with stones, 21 cases (11.35\%) had stone size less than 1 c, 109 (58.92\%) had stone size between
$1-1.9 \mathrm{~cm}, 45(24.32 \%)$ had stone size between $2-2.9 \mathrm{~cm}$ and rest $10(5.41 \%)$ had stone size $\geq 3 \mathrm{~cm}$. The maximum stone size observed was $4.0 \mathrm{~cm}$. In 4 out of 6 cases of malignancy, the stone size was $<3 \mathrm{~cm}$ and in 2 cases it was $\geq 3 \mathrm{~cm}$. In 172 out of 179 gall bladders with benign pathology, stone size was $<3 \mathrm{~cm}$. and in 7 cases, it was $\geq 3 \mathrm{~cm}$. As $\mathrm{p}<0.005$, there is a significant correlation between stone size and gall bladder cancer (Table 2).

\section{Type of stones}

Out of 185 gall bladders with calculi, mixed stones were present in 168 cases $(90.8 \%)$, pure cholesterol stones in 13 cases $(7.03 \%)$, pure pigmented stones in 3 cases $(1.62 \%)$ and combined stone in only 1 case. Grossly, in majority of the cases, the mixed stones were multifaceted, grayish-white in color. Their cut surface showed yellow colored radiating crystals with a black centre. Cholesterol stones were mostly solitary, round to oval and yellow in color, with a finely granular and crystalline surface. On fracture, they showed large flat crystals. Pigmented stones were brown black in color and were mostly multifaceted. Combined gall stone was found in a single gall bladder and was single and large in size. Its cut surface showed central nucleus and outer shell. Benign gall bladder lesions were mostly associated with mixed type of stones while in majority (4 out of 6 ) of the malignant cases, there were pure cholesterol type of stones. As $\mathrm{p}<0.001$, there is highly significant risk of progression to gall bladder cancer in patients with cholesterol gall stones (Table 2). Thus, gall stones are one of the risk factors responsible for progression to GBC and more so, in patients having larger multiple cholesterol stones.

TABLE 3: Correlation between patients' lipid profile and gall bladder pathology $(\mathrm{n}=200)$

\begin{tabular}{|c|c|c|c|c|}
\hline Pathology & $\begin{array}{c}\text { S.Chol } \\
\text { Mean + } \\
\text { S.D } \\
\text { (range) } \\
\text { (mg/dl) }\end{array}$ & $\begin{array}{c}\text { HDL } \\
\text { Mean + } \\
\text { S.D } \\
\text { (range) } \\
\text { (mg/dl) }\end{array}$ & $\begin{array}{c}\text { TG } \\
\text { Mean + } \\
\text { S.D } \\
\text { (range) } \\
\text { (mg/dl) }\end{array}$ & $\begin{array}{c}\text { LDL } \\
\text { Mean + } \\
\text { S.D } \\
\text { (range) } \\
\text { (mg/dl) }\end{array}$ \\
\hline $\begin{array}{l}\text { Benign } \\
\text { Lesion }\end{array}$ & $\begin{array}{c}194.36 \pm \\
36.3 \\
(145-320)\end{array}$ & $\begin{array}{c}51.04 \pm \\
13.26 \\
(20-76)\end{array}$ & $\begin{array}{c}121.6 \pm \\
47.86 \\
(30-210)\end{array}$ & $\begin{array}{c}138.08 \pm \\
15.25 \\
(114-180)\end{array}$ \\
\hline Malignant & $\begin{array}{c}186 \pm \\
54.21 \\
(101-270)\end{array}$ & $\begin{array}{c}47 \pm 18.44 \\
(27-78)\end{array}$ & $\begin{array}{c}123 \pm \\
59.21 \\
(49-200)\end{array}$ & $146 \pm 23.2$ \\
\hline $\begin{array}{l}\mathrm{t} \text {-value } \\
\text { p-value }\end{array}$ & $\begin{aligned} & 0.38 \\
> & 0.005\end{aligned}$ & $\begin{aligned} & 0.53 \\
> & 0.005\end{aligned}$ & $\begin{array}{c}0.006 \\
>0.005\end{array}$ & $\begin{aligned} & 0.83 \\
> & 0.005\end{aligned}$ \\
\hline Significance & $\begin{array}{c}\text { Not } \\
\text { significant }\end{array}$ & $\begin{array}{c}\text { Not } \\
\text { significant }\end{array}$ & $\begin{array}{c}\text { Not } \\
\text { significant }\end{array}$ & $\begin{array}{c}\text { Not } \\
\text { significant }\end{array}$ \\
\hline
\end{tabular}

Serum Cholesterol (S.Chol); High Density Lipoprotein (HDL); Triglyceride (TG); Low density lipoprotein (LDL)

\section{Lipid Profile}

Mean values of fasting serum cholesterol, HDL, triglycerides and LDL were almost similar in patients with benign lesions and those with malignancy. As $\mathrm{p}>0.005$, there is no signifi- 
cant correlation between the patient's serum lipid profile and GBC (Table 3).

\section{Discussion}

In Northern India, gallstones are seven times more common with overall incidence of about $2.29 \%$. This study was done to find out relationship between size, number and type of gall stones with the occurrence gall bladder cancer and also to see its relation with lipid profile. This study comprised of total 200 cholecystectomy cases out of which, $88 \%$ were from female patients. It is a well-established fact that biliary system of females is affected more frequently than those of the males. According to a few authors, it is the disease of fair sex only. Incidence of female preponderance in this study comparable with other studies. ${ }^{16,}$ 25-28 Why females suffer more is unclear. Some authors have linked estrogen and sex hormones with gall bladder disease presuming that estrogen metabolism in the liver produces an irritant chemical which causes inflammation and subsequently infection in the biliary passages. This hypothesis is further supported because majority of females are afflicted by the disease in their reproductive period when estrogen levels are at the peak. Higher and extended exposure to female sex hormones (such as estrogen and progesterone) may be a main factor. Therefore, early menarche, early first pregnancy, multiple pregnancies and delayed menopause may increase the risk of gallbladder carcinoma. ${ }^{29}$

In the present study, chronic cholecystitis was the commonest lesion found and malignancy was seen in only 6 cases (3\%). This may be because early development of symptoms in cholecystitis cases and subsequent cholecystectomy would not have allowed enough time for dysplasia to develop. Also that carcinoma is more likely to be found in patients with asymptomatic gall stones because they would have been present in gall bladder over a longer period of time. A Indian study recommends prophylactic cholecystectomy for asymptomatic gallstones in young patients with thickened gallbladder wall (greater than $3 \mathrm{~mm}$ ); with large gallstones (greater than $3 \mathrm{~cm}$ ); and patients with porcelain gallbladder, sessile polyps (greater than $1 \mathrm{~cm}$ ), anomalous pancreaticobiliary junction, race and/or habitants of geographical locations with high incidence rates of gallbladder cancer. ${ }^{30}$ Nevertheless, even though there are indications that performing prophylactic cholecystectomies in patients with asymptomatic gallstones may reduce the mortality rate of gallbladder cancer, this subject is still controversial.

The relationship between gall stones and GBC has been well established in literature. In our study, gall stones were found in all 6 cases of malignancy and a significant association was found between the number and size of stones with GBC. The possible explanation behind this is that when gallbladder gets with packed stones there may be interfere with the mechanical functioning of gall bladder which may be a prereq- uisite step to eventual malignancy. The high risk of GBC with large stones may be explained by a longer duration of exposure to gall stones. This is also consistent with the view that GBC is found mostly in older age group patients.

Gall stones cause mechanical damage on the mucosa of gall bladder, this may be followed by compensatory tissue growth, which may serve to enhance carcinogenesis. Thus constant erosion of the gall bladder wall by gall stones over prolonged time may constitute the risk for malignancy.

The almost complete occupation of the gall bladder lumen by numerous and large gallstone could be a significant marker for the increase in risk for GBC. The repeated mechanical irritation of gall bladder mucosa by these stones may be responsible for the causation of GBC. This may well explain the positive association between gall stone size ${ }^{6,31}$ and number ${ }^{32-34}$ with GBC as observed in our study. But this is in contradiction to the study by Moerman et al. ${ }^{35}$ who did not find any association between stone size and GBC.

We also observed that majority of the malignant cases had pure cholesterol type of stones and none of these had either brown or black pigment stones hence supporting the previous reports of association of GBC with cholesterol stones. ${ }^{33,36 \text {, }}$ ${ }^{37}$ Our findings are similar to a study from Japan by Kimura et al. ${ }^{38}$ which revealed that though most common type of stones were of pigmented type, but in patients with GBC cholesterol gall stones are most commonly found. Lorna and Cooke ${ }^{32}$ however, recorded association of mixed type of stones with GBC. The possible association between cholesterol stones and GBC cases could be changing life styles, more westernized diet and increasing obesity. Rijvi and Zuberi ${ }^{39}$ also revealed that risk of developing GBC is associated with low calorie, high fat and low fiber intake. It is proposed that they are linked at molecular level such that there is simultaneous pumping of cholesterol (which precipitate as gall stones) and a food carcinogen into the bile in gall bladder, the latter cause's malignant transformation.

In the present study, no correlation was found between patients' lipid profile and gall bladder pathology (Table -3). The mean values of serum cholesterol, HDL, triglycerides and LDL were almost similar in patients with benign lesions and those with malignancy. The study by Aulakh et al. ${ }^{28}$ also did not show any significant role of serum lipids in the causation of gall bladder disease. Thus patients' lipid profile may not have an important role in the causation of gall bladder disease. Although our study did not prove any significant correlation between serum lipids and GBC, there is need of further studies in order to clarify the risk factors about gallbladder cancer.

This small sample size study concluded that there is correlation between presence of gallstones and increased risk of carcinoma gallbladder but a larger sample 
size study is required to further strengthen these risk factors. The understanding of various risk factors is essential to establish surgical treatments for the various pathological gallbladder conditions, such as symptomatic or asymptomatic calculouscholecystitis.

\section{Conclusion}

This small sample study has established the link between gallstones and malignancy gallbladder. Nonetheless further work is needed to understand various risk factors and to establish surgical treatments for the various pathological gallbladder conditions, such as symptomatic or asymptomatic calculouscholecystitis.

\section{Conflict of interest}

The authors declare that they have no conflicts of interest. The authors alone are responsible for the content and writing of the paper.

\section{References}

1. Lazcano-Ponce EC, Miquel JF, Muñoz N, et al. Epidemiology and molecular pathology of gall bladder cancer. CA Cancer J Clin 2001; 51:349-64.

2. Randi G, Franceschi S, La Vecchia C. Gall bladder cancer worldwide: Geographical distribution and risk factors. Int J Cancer 2006; 118:1592-602.

3. Curado MP, Edwards B, Shin HR, et al. Cancer Incidence in Five ContinentsVol IX. (IARC)Scientific Publications, No.160.International Agency for Research Cancer, Lyon, France, 2007.

4. Strom BL. Epidemiological and biochemical aspects of an important sequel to cholelithiasis: Gallbladder cancer. In: Capocaccia G, Ricci F, Angelico F, (eds) Epidemiology and Prevention of Gallstone Disease. MTP Press, Lancaster 1984; 64-76.

5. Diehl AK. Epidemiology of gallbladder cancer: a synthesis of recent data. I Natl Cancer Inst 1980; 65:1209-14.

6. Diehl AK. Gallstone size and the risk of gallbladder cancer. JAMA 1983; 250:2323-6.

7. Black WC, Key CR, Carvant JB, et al. Carcinoma of the gall bladder in a population of South-Western American Indians. Cancer 1977; 39:1267-79.

8. Lowewfels $A B$, Lindstrom CG, Conway MJ, et al. Gallstone and risk of gall bladder cancer. J Natl Cancer Inst 1985; 75:77-80.

9. Hart J, Modan B, and Shanti M. Cholelithiasis in the etiology of gall bladder neoplasm. Lancet 1971; 1:1151-3.
10. Kato K, Akai S, Toninga S, Kato I.A case-control study of biliary tract cancer in Niigata Prefecture, Japan. Jpn J Cancer Res 1989; 80:932-8.

11. Zantonski WA, La Veccia C, Przewozniak K, et al. Risk factors for gallbladder cancer: a Polish case-control study. Int J Cancer 1992; 51:707-11.

12. Malik IA, Aziz Z, Zaidi SH, Sethuraman G. Gemcitabine and Cisplatinis a highly effective combination chemotherapy in patients with advanced cancer of the gallbladder. Am J Clin Oncol 2003; 26: 174-7.

13. Kapoor VK, Mcmichael AG. Gallbladder Cancer: An 'Indian' disease. Natl Med J India 2003; 16:209-13.

14. Maram ES, Ludwig J, Kurland LT, Brian DD. Carcinoma of the gallbladder and extrahepatic biliary ducts in Rochester, Minnesota, 1935-71. Am J Epidemiol 1979; 109:152-7.

15. Nervi F, Duarte I, Gomez G, et al. Frequency of gallbladder cancer in Chile, a high-risk area. Int $J$ Cancer 1988; 41:657-60.

16. Gupta SC, Mishra V, Singh PA, et al. Gall stone and carcinoma gall bladder. Indian J Pathol Microbiol 2000; 43:147-54.

17. Hsing AW, Rashid A, Devesa SS, et al. Biliary tract cancer. In: Schottenfeld D, Fraumeni JF, Jr, eds. Cancer epidemiology and prevention. $3^{\text {rd }}$ edn. Oxford: Oxford University Press, 2006; 787-800.

18. deGroen PC, Gores GJ, LaRusso NF, et al. Biliary tract cancers. N Engl J Med 1999; 341:1368-78.

19. Tandon RK. Current developments in the pathogenesis of gall stones in India. Tropical Gastroenterol 1990:11:130-9.

20. OserLB. Analysis of biliary calculi. Hawk's physiological chemistry. 14 ${ }^{\text {th }}$ edn McGraw Hill; 1971: 497.

21. Allan CC, Porn LS, Chan CS, et al. Enzymatic determination of total serum cholesterol. Clin Chem 1974; 20:470-5.

22. McGowan MW, Artiss JD, Strandbergh DR, Zak B. A peroxidase coupled method for the calorimetric determination of triglycerides. Clin Chem 1983; 29:538-42.

23. Burstein M, Schalnick HR, Morfin R. Rapid method for the isolation of lipoproteins from human serum by precipitation with polyanions. J Lipid Res 1970; 11:583-95.

24. Friedewald WT, Levy RS, Friedricksen DS. Estimation of concentration of low density lipoprotein cholesterol in plasma without rise of preparative ultracentrifuge. Clin Chem 1972; 18:499-502.

25. Adam R,Stranahan A. Cholecystitis and cholelithiasis; an analytical report of 1,104 operative cases. Surg Gynecol Obstet 1947; 85:776-84.

26. Glenn F, Frey C. Re-evaluation of the treatment of pancreatitis associated with biliary tract diseases. Ann Surg 1964; 160: 723-36. 
27. Khanna R, Chansuria R, Kumar M, Shukla HS. Histological changes in gallbladder due to stone disease. Indian J Surg 2006; 68:201-4.

28. Aulakh R, Mohan H, Attri AK, et al. Comparative study of serum lipid profile and gallstone disease. Indian J Pathol Microbiol 2007; 50:308-12.

29. Meirelles-Costa AL, Bresciani CJ, Perez RO, et al. Are histological alterations observed in the gallbladder precancerous lesions? Clinics (Sao Paulo) 2010; 65: 143-50

30. Kapoor VK. Cholecystectomy in patients with asymptomatic gallstones to prevent gall bladder cancer--the case against. Indian $J$ Gastroenterol 2006; 25:152-4.

31. Lowenfels AB, Walker AM, Althaus DP, et al. Gallstone growth, size, and risk of gallbladder cancer: An interracial study. Int J Epidemiol 1989; 18:50-4.

32. Cooke L, Jones FA, Keech MK. Carcinoma of the gall-bladder; a statistical study. Lancet 1953; 1:585-7.

33. Vitetta L, Salia A, Little P, Mrazek L. Gall stones and gall bladder carcinoma. Aust N ZJ Surg 2000; 70: 667-73.
34. Roa I, Ibacache G, Roa J, et al. Gall stones and gall bladder cancer-volume and weight of gall stones are associated with gall bladder cancer: A case control study. J Surg Oncol 2006; 93:624-8.

35. Moerman CJ, Lagerwaard FJ, Bueno de Mesquita $\mathrm{HB}$, et al. Gallstone size and the risk of gallbladder cancer. Scand J Gastroenterol 1993; 28: 482-6.

36. Venniyoor A. Cholesterol gallstones and cancer of gallbladder (CAGB): molecular links. Med Hypotheses 2008; 70:646-53.

37. MisraVatsala, Misra SP, Singh PA, et al. Significance of cytomorphological and microbiological examination of bile collected by endoscopic cannulation of the papilla of vater. Indian J PatholMicrobiol 2009; 52: 328-31.

38. Kimura W, Shimada H, Kuroda A, Morioka Y. Carcinoma of the gall bladder and extrahepatic bile duct in autopsy cases of the aged, with special reference to its relationship to gall stones. Am J Gastroenterol1989; 84:386-90.

39. Rizvi TJ, Zuberi SJ. Risk factors for gall bladder cancer in Karachi. J Ayub Med Coll Abbottabad 2003; 15: 16-8. 